\title{
An Insight to Students' Perceptions on Teacher Feedback in Second Language Writing Classes
}

\author{
Meral Seker ${ }^{1} \&$ Ayca Dincer ${ }^{1}$ \\ ${ }^{1}$ School of Foreign Languages, Cukurova University, Adana, Turkey \\ Correspondence: Meral Seker, School of Foreign Languages, Cukurova University, Balcali, 01330, Adana, \\ Turkey. Tel: 90-322-338-6084. E-mail: sekerm@cu.edu.tr
}

Received: October 28, 2013 Accepted: December 5, 2013 Online Published: January 6, 2014

doi:10.5539/elt.v7n2p73 URL: http://dx.doi.org/10.5539/elt.v7n2p73

\begin{abstract}
Feedback is one of the crucial elements in language learning and teaching. In second language writing context, the effectiveness of feedback becomes even more important as it has an impact on the whole process of language learning. To increase the effectiveness of feedback, a teacher is expected to use any possible mean(s) available to suit learners' needs and concerns (Hamp-Lyons, 2001; Hyland, 2010). In this respect, rather than framing the feedback process based on the premises put forward in other teaching situations, the study attempts to bring into view the students' perceptions and preferences on feedback in their writing classes to be able to shape the feedback process based on a specific teaching context. The data for the study were gathered utilizing a Likert-Type questionnaire and a semi-structured interview from students $(n=457)$ at preparatory level studying English at a state university in Turkey. The data were analyzed quantitatively using SPSS 17.0 and qualitatively following content analysis. The results of the study are meant to bring in-depth insights to students' opinions regarding the scope of feedback in writing classes and to provide guidance to shape the process of giving feedback.
\end{abstract}

Keywords: second language writing, writing instruction, feedback, teacher feedback, students' perceptions

\section{Introduction}

Feedback is one of the fundamental tools used to provide effective interaction in teaching-learning contexts. Narciss (2008, p. 292) defines the term "feedback" in any teaching context as "[the] post-response information which informs the learners on their actual states of learning and/or performance in order to help them detect if their states corresponds to the learning aims in a given context".

The scope of feedback has a vital impact on the process of any specific learning situation. The feedback provided by a teacher will determine the progress of learners, the pedagogical and assessment intentions and expectations of the teacher and the institution, the degree of student engagement in the learning process, and the revision responses expected from learners (Parr \& Timperley, 2010). By deciding on a specific type of feedback, a writing teacher can put emphasis on form, content, discourse, punctuation, or any other language item in isolation or in combination with multiple aspects.

In a writing classroom context, feedback has a vital role serving multidimensional function. In addition to assessment purposes, it has a larger pedagogical role “...by pointing forward to other texts students will write, assisting students to work out the text's potential and to comprehend the writing context, and providing a sense of audience and an understanding of the expectations of the communities they are writing for" (F. Hyland \& K. Hyland, 2006b, p. 206). When used effectively, it can also act as a medium of interaction between student-teacher and student-student and trigger revisions, which subsequently foster language improvement (Hyland, 1998; Ferris, 1997) and contribute to the process of learning when the nature of it is well chosen (Balzer, Doherty, \& O’Connor, 1989; Kluger \& Denisi, 1998).

However, in second language instruction, identifying the scope and the format of providing feedback for learners' writings has always been controversial. The ongoing debate is multifaceted. While educators' views display divergent implications for the feedback process in writing classes, the studies conducted on students' opinions and attitudes also present disparate results. 


\subsection{The Scope of Feedback in Second Language Writing: Educators' View}

Although providing quality and encouraging feedback is mostly accepted to be an important component of teacher practice in writing classes (e.g. Lee, 2007; Gielen, Peeters, Dochy, Onghena, \& Struyyen, 2010; Parr \& Timperley, 2010; Strijbos, Narciss, \& Dünnebier, 2010; Li \& Barnard, 2011), there are divergent suggestions regarding what makes a quality feedback. Some researchers argue that feedback on students' writing tasks should include comments on form (e.g. Zamel, 1985; White \& Arndt, 1991; Polio, Fleck, \& Leder, 1998; Ferris \& Helt, 2000; Ferris, 2002; F. Hyland \& K. Hyland, 2006a), others claim that giving feedback on content should be prior to form (e.g. Frantzen, 1995; Truscott, 1996; Reid, 1998). Yet, there are other researchers who suggest that both form and content should be considered simultaneously in giving feedback (Taylor, 1981; Sommers, 1982; Krashen, 1984; Ferris, 1999). However, the experimental study conducted by Ashwell (2000) showed no significant differences in scores of students who received feedback on content then form; on form then content; on form and content simultaneously; and no feedback. The researcher concluded that manipulating the content of feedback given to students or ordering them in terms of importance did not have any effect on students' overall scores.

\subsection{The Scope of Feedback in Second Language Writing: Students' View}

The research focusing on students' feedback preferences displays divergent results. In regards to feedback types, some studies indicate that students prefer comments on content and ideas rather than on grammatical errors (e.g. Semke, 1984; Zamel, 1985). Yet, other studies show that students demand feedback on their grammatical errors (Leki, 1991; Ashwell, 2000; Lee, 2005). Still, there are also results indicating that students expect various types of feedback including content-related, grammatical and organizational aspects (e.g. Radecki \& Swales, 1988; Ferris, 1995; Lee, 2005).

Most of the research in the field, on the other hand, meets on the ground that students and teachers need to agree on the effective feedback types and strategies (Leki, 1991; Raimes, 1991; Saito, 1994; Schulz, 1996, 2001; Diab, 2005; Plonsky \& Mills, 2006). However, studies have also revealed that such a match in the preferences does not come naturally. When there is no prior investigation, pre-planning or training, a match in the feedback preferences of students and teachers is almost circumstantial (Saito, 1994; Hyland, 1998; Diab, 2005; Montgomery \& Baker, 2007). However, when students are included actively in the process of defining the scope of feedback, the chance of meeting both students' and the institutions' needs may increase (e.g. Plonsky \& Mills, 2006).

Moving from these discussions, it seems that adopting a strategy for feedback based on the outcomes of other learning contexts may not meet the specific needs of our students. As Joughin (2008) states, when teachers expect students to understand the academic standards of the learning situation and to try to improve their performance based on teachers' judgments on their current achievements through feedback, they may fail to consider that professional or academic standards are not always clear for students since these standards are derived from context-free theoretical perspectives. Therefore, rather than meeting the pre-specified learning and teaching standards, students may benefit more from feedback which is based on the specific setting and the contextual constraints such as linguistic, educational, socio-economic and cultural background of the learners to suit their specific needs (e.g. Hamp-Lyons, 2001; Amrhein \& Nassaji, 2010; Bailey \& Garner, 2010). Since the way they receive feedback will determine students' course of action and the possible subsequent learning (Black \& Wiliam, 1998), teachers need to acknowledge the importance of student involvement and place room for their needs and preferences (Hyland, 2010). To achieve this, there should be a dynamic interaction between the teacher and learners to communicate the needs and the expectations of both parties. A good number of studies suggest that students are eager to gain opportunities to voice their needs and to experiment with different feedback options (e.g. Leki, 1991; Master, 1995; Wiliam, 2001; Lee, 2007).

\section{Method}

\subsection{Aim of the Study}

Based on the argument that any decision in the process of receiving and giving feedback should be based on the learning context and should place a greater emphasis on identifying students' opinions (e.g. Goldstein, 2005; Inoue, 2005; F. Hyland \& K. Hyland, 2006b), the present study attempts to contribute to improving feedback process in writing lessons by identifying students' views and expectations. It is expected that taking the first step by determining students' perceptions can lead to create a more efficient feedback environment in our context and may bring new insights to feedback strategies applied in the field of second language writing instruction.

The study specifically aims to find answers to the following research questions: 
1. What are the types of the feedback students mostly receive?

2. What are the types of the feedback students mostly prefer?

3. How do students evaluate the impact of feedback they receive in writing classes on their foreign language improvement?

4. What are the students' affective dispositions toward the feedback they receive?

5. When do students act upon the feedback they receive?

\subsection{Context and the Participants}

The study was conducted at Foreign Language School at a state university in Turkey. The school provides one year of preparatory education to students below C1 English proficiency level to improve their English before they start their education at various departments. The preparatory education lasts two terms $(4+4$ months $)$ and divided into four blocks $(2+2+2+2$ months). In each block, students follow the school's curriculum, which provides education to improve students' basic language skills, i.e. reading, writing, speaking, listening, and grammar. Students are administered a placement test at the beginning of the academic year and placed to Total Level 1 (A1 Level), False Level 1 (A2 Level), L2 (B1 Level), or to Level 3 (B2 Level) classes. Each level follows a course book in line with their language proficiency level and extra materials which are given each week and prepared by the Syllabus and the Material Production Units.

Students have 20 to 24-hour English instruction a week and the program devotes 3-6 hours to writing instruction per week. In addition to the writing tasks in the course books, students also study supplementary tasks provided by the school's syllabus unit, which are all kept in writing portfolios. Among the writing tasks that students study during the year, there are formal/informal e-mails, formal/informal letters, cover letter, report, paragraph studies (e.g. narrative, advantage/disadvantage, cause/effect), and different types of essays (e.g. compare-contrast, cause-effect, expository, and argumentative). Students are assigned the tasks and given feedback by their class teachers. However, the school does not have a standard policy regarding the type or the format of feedback teachers give on students' writings. In other words, teachers are free to apply their own approaches to giving feedback.

The feedback provided to students serves two purposes: firstly, it serves as a tool to provide constant evaluation and assistance throughout the language learning process. In order to help students improve their writing by reviewing the process and identifying their strengths and weaknesses, teachers check the first drafts and hand the assignments back to students providing written and spoken feedback. Based on the feedback they receive, students work on their assignments and try to improve it before handing in the second draft. If the second draft still needs improvement, the teacher provides further feedback and hands the assignment back to students. This process is followed until students meet the assignment requirements. The second purpose is assessing students' final writing products. The writing assessment procedure is students keep writing portfolios all through four blocks and the assignments in these portfolios are graded at the end of each block comprising $20 \%$ of their grades.

The sample for the study consisted of 468 students who studied English as a foreign language in A1, A2, and B1 Levels. Their majors were engineering $(n=174)$, economics $(n=196)$, and science $(n=108) .196$ of them were female and 272 of them were male. Their ages varied between 17 and 21.

\subsection{Instrumentation and Procedure}

The data for the study emerged from two sources: "Student Questionnaire for Feedback Experiences" and semi-structured interviews with students. Based on a comprehensive literature review in the field and interviews with English Language teachers $(n=11)$, a questionnaire was developed to explore students' opinions on receiving feedback in their writing classes. The questionnaire was designed in two parts. The first part included questions to obtain demographic information, namely gender, age, majoring fields and language proficiency level. The second part, consisted 57 items in 5-point Likert Scale format, anchored by strongly agree (1) and strongly disagree (5). The items were originally directed towards students' underlying constructs regarding (a) the types of feedback they receive; (b) the types of feedback they prefer to receive; (c) students' opinions on the impacts of receiving feedback on their foreign language improvement; (d) students' emotional dispositions toward feedback; and (e) students' action initiation time upon feedback.

Following Gorsuch's (1983) proposal to have a minimum of five participants per variable, the questionnaire was administered to a large sample of students $(n=468)$. When the students were asked to complete the questionnaire, they had already completed the first two blocks of English Language education and were familiar 
with feedback procedure that their teachers followed. After the administrative and individual permissions were attained, they were asked to complete the questionnaire at school. They were given as much time as they needed and assisted by one of the researchers to answer any questions by students.

After participants completed the questionnaire, the data were manually transferred to computer environment by the researchers. 11 items were excluded from the analysis since 4 of them were not totally completed and 7 of them had unclear markings. The total number of the items included to statistical analysis was 46 . For the evaluation of the questionnaire, SPSS 17.0 (Statistical Package for Social Sciences) was used.

The scale's reliability was measured using Cronbach's Alpha Coefficient (Cronbach, 1951). The reliability test result indicated that the scale had high internal reliability $(\alpha=0.859)$ and was suitable to conduct further statistical tests.

Factor Analysis was conducted for the data from the questionnaires to acquire a standard scale before proceeding to further statistical analyses. The main motive behind creating a standard scale is to both increase the validity of our findings and generate a valid tool for further investigations in a given context. Furthermore, the analysis enabled us to have a clearer picture of the large number of data sets by first showing what factors underlie the variables in the scale (Bryman \& Cramer, 2003); and second, by reducing the numbers of correlating variables into more meaningful and significant sets by differentiating the correlating variables under independent factors.

The Factor Analysis involved four steps. In the first step, both Kaiser-Meyer-Olkin (KMO) Test and Bartlett's Test were conducted to find out if the data sets were suitable for further analysis. The results showed high correlation among variables $(\mathrm{KMO}=0.873 ; \mathrm{p}=0.00<0.05)$ and indicated that factor analysis could be measured for these data sets. The second step involved determining the number of factors. To identify the number of significant factors, Initial Eigenvalue analysis was conducted. The results revealed 6 factors consisting of 43 items in total with greater than 1 scores (Tables 1,2,3 and 4). The first 6 factors accounted for $61.05 \%$ of the total sum. The items with values smaller than 1 were eliminated $(n=14)$ based on Kaiser's Criterion (Kalayci, 2010) since they did not have significant correlations with any of the factors. To confirm the items to be excluded from the analysis, we also conducted Scree Test. (Cattell, 1966) The Scree Test of Eigenvalues showed the same number of factors $(n=6)$ to have greater than 1 value.

The semi-structured interviews were conducted with a smaller sample of volunteering students $(n=21)$ following the Factor Analysis of the questionnaire and included questions directed mostly to the reasons of and further comments on their responses to the questionnaire to have a broader perspective on students' opinions regarding various aspects of receiving feedback. From each class in the school, one student was chosen randomly to be able to include students' opinions on feedback given by all the teachers at the institution. Students' responses were recorded and transcribed verbatim. The responses were analyzed through a systematic content analysis. Following a model of "stakeholder research" (H. Hodkinson \& P. Hodkinson, 1999), we adopted an interpretive approach in order to reach a complete understanding of students' comments. Accordingly, the transcribed responses were analyzed by one of the researchers first and by the second researcher afterwards. A double-check was possible in the discussion between the researchers before finalizing the content analysis of the interviews.

\section{Results}

Orthogonal Rotation analysis enabled us to list the items under the factor in which they correlate the highest and to form the items in groups to constitute different factors. According to the results, items 2, 19, 24, 35, 45, 50, 54 load highest in Factor 1 and form a high correlation. The second factor shows items 10, 22, 23, 28, 39, 48, 59, 65 to load higher within this group, and so on. As a result of this rotation, it was possible to group and name the items in subscales under the correlating factors $(n=43)$. The results are presented in four different groups: (1) items related to the types of feedback students receive (FTR) and prefer (FTP), (2) the effect of feedback on their language improvement (LI); (3) the students' affective dispositions toward receiving feedback (FE) and their feelings when waiting long to receive feedback (FEWL); and (4) the duration for students' action initiation (ACD).

\subsection{Types of Feedback}

The loadings of items on the first two factors and the amount of the variance they account for are presented in Table 1: 
Table 1. Item loadings for type of feedback received and type of feedback preferred

\begin{tabular}{lcc}
\hline Items & Factor 1 (FTR) & Factor 2 (FTP) \\
\hline 2. I receive teacher feedback on organization. & 0.785 & \\
19. I receive teacher feedback on punctuation. & 0.528 & \\
24. I receive teacher feedback on spelling. & 0.675 & \\
35. I receive teacher feedback on capitalization. & 0.680 & \\
45. I receive teacher feedback on grammar points. & 0.405 & \\
50. I receive teacher feedback on vocabulary. & 0.658 & \\
54. I receive teacher feedback on content. & 0.545 & \\
10. I prefer receiving teacher feedback for capitalization. & & 0.736 \\
12. I prefer receiving teacher feedback for organization. & & 0.507 \\
22. I prefer receiving teacher feedback for grammar. & & 0.402 \\
23. I prefer receiving teacher feedback for spelling. & & 0.598 \\
28. I prefer receiving teacher feedback for punctuation. & & 0.777 \\
30. I prefer receiving teacher feedback for content. & & 0353 \\
39. I prefer receiving teacher feedback for all mistakes and suggestions. & & 0.628 \\
48. I prefer receiving teacher feedback for vocabulary. & & 0.620 \\
\hline
\end{tabular}

*FTR: Type of Feedback Students Receive. FTP: Type of Feedback Students Prefer.

The results in Table 1 reveal that seven items (Item 2, 19, 24, 35, 45, 50, and 54) related to the types of the feedback that students receive for their writing assignments factored together (F1: FTR). The Mean scores show that students mostly receive feedback on organization, grammar, and spelling $\left(\mathrm{M}_{2}=1.86, \mathrm{M}_{45}=1.94, \mathrm{M}_{24}=\right.$ 1.96). They also rated content, vocabulary, capitalization, and punctuation with high frequencies $\left(\mathrm{M}_{54}=2.17\right.$, $\mathrm{M}_{50}=2.10, \mathrm{M}_{35}=2.66$, and $\mathrm{M}_{19}=2.62$ ).

As for the feedback types students prefer, eight items (Items 10, 12, 22, 23, 28, 30, 39, 48) loaded significantly forming another factor (F2: FCP). The analysis indicate that they prefer to receive feedback for all the mistakes in their writings $\left(\mathrm{M}_{39}=1.65\right)$. Surprisingly, students in our study expressed high preferences to receive feedback focusing on grammatical accuracy $\left(\mathrm{M}_{22}=1.83\right)$. They also stated that they wanted feedback on capitalization $\left(\mathrm{M}_{10}=2.74\right)$, spelling $\left(\mathrm{M}_{23}=2.32\right)$, punctuation $\left(\mathrm{M}_{28}=2.60\right)$, vocabulary $\left(\mathrm{M}_{48}=2.04\right)$, content $\left(\mathrm{M}_{30}=2.01\right)$, and organization $\left(\mathrm{M}_{12}=2.26\right)$.

In order to be able to investigate any statistically significant difference between these two factors, Principal Component Analysis was conducted to transform items in FTR and FTP Factors into a single mean value for the whole factor. This analysis enabled us to have two mean values to represent the items in each factor. The subsequent Wilcoxon Signed Ranks Test indicated that there is no significant difference between the type of feedback that students receive and the type they prefer to receive (Negative Mean Rank $=220.34$; Positive Mean Rank $=218.64 ; Z=-0.319 ; p=0.750>0.05$ ). The interview results, as exemplified in Excerpts 1 and 2, provide reasons by students:

\section{Excerpt 1:}

I always receive feedback on my grammar usage, and I think this is really the best for me because I frequently make grammar mistakes. (Hasan)

\section{Excerpt 2:}

I receive feedback mostly on vocabulary and outlining my essay. I prefer to get comment on these because they are the most difficult parts for me. (Anil)

Analyzing the results, it was found that students received feedback mostly on grammar, content, vocabulary, and organization and less frequently on punctuation, capitalization, and spelling. When asked for their preferences, feedback on grammar mistakes had the highest rate. Yet, they also stated that they wanted feedback on all writing aspects. To sum up, students were satisfied with the types of feedback they received since they thought these 
were the difficult but useful aspects for them in writing.

\subsection{Impact of Feedback on Students' Language Improvement}

The analysis showed nine items (Items 3, 8, 13, 17, 29, 31, 37, 41, 52) with significant correlations under the third factor (F3: LI) directed toward the effects of different feedback types on students' foreign language improvement as shown in Table 2.

Table 2. Item loadings for feedback effect on language improvement

\begin{tabular}{lc}
\hline Items & Factor 3 (LI) \\
\hline 3. I find feedback related to punctuation useful for my language improvement. & 0.515 \\
8. I find feedback related to organizational points useful for my language improvement. & 0.366 \\
13. I find feedback related to capitalization useful for my language improvement. & 0.713 \\
17. I find feedback in all writing areas useful for my language improvement. & 0.513 \\
29. I find feedback related to spelling useful for my language improvement. & 0.524 \\
31. I find feedback related to vocabulary usage useful for my language improvement. & 0.658 \\
37. I find feedback related to grammar points useful for my language improvement. & 0.450 \\
41. I find feedback related to content useful for my language improvement. & 0.509 \\
52. I don't find any type of feedback useful for my language improvement. & 0.774 \\
\hline
\end{tabular}

*LI: Feedback Effect on Language Improvement.

As Table 2 shows, the mean scores of the items in F3 (LI) revealed that students found all feedback types useful for their language improvement $\left(\mathrm{M}_{17}=1.81\right)$. Among these, they rated grammar, vocabulary, and content aspects to be most beneficial $\left(\mathrm{M}_{37}=1.58, \mathrm{M}_{31}=1.58, \mathrm{M}_{41}=1.72\right)$. The other aspects of language items were also scored significantly high $\left(\mathrm{M}_{29}=1.85, \mathrm{M}_{3}=1.99, \mathrm{M}_{8}=1.91, \mathrm{M}_{13}=2.31\right)$. Students expressed their reasons in the interview:

Excerpt 3:

We mostly receive feedback for grammar and choosing the suitable words. These can help me learn more about English because a word in English has more than one meaning and I cannot choose the right one when I think in Turkish" (Mesut).

Excerpt 4:

My teacher checks my writing in terms of grammar mistakes and gives comments if the content of my essay is not suitable. I think grammar is basic in language learning. So, I want feedback on grammar mistakes" (Suat).

3.3 Students' Affective Dispositions toward Feedback

The other two factors included items related to students' feelings when they received feedback to their writing assignments (FE) and their feelings when they wait long for feedback (FEWL). The items and their loadings are displayed in Table 3:

Table 3. Item loadings for students' feelings toward receiving feedback

\begin{tabular}{lcc}
\hline Items & Factor 4 (FE) & Factor 5 (FEWL) \\
\hline 6. I feel frustrated when I get my teacher's feedback. & -0.355 & \\
15. I feel demotivated when I get my teacher's feedback. & 0.745 & \\
27. I feel humiliated when I get my teacher's feedback. & 0.731 & -0.456 \\
33. I feel unsatisfied when I get my teacher's feedback. & 0.680 & \\
38. I feel cared for when I get my teacher's feedback. & 0.496 & \\
46. I feel disappointed when I get my teacher's feedback. & 0.575 & \\
49. I feel improved when I get my teacher's feedback. &
\end{tabular}


53. I feel assessed when I get my teacher's feedback.

55. I feel satisfied when I get my teacher's feedback.

7. I get demotivated when I have to wait long for my feedback.

20. I get frustrated when I have to wait long for my feedback.

34. I get impatient when I have to wait long for my feedback.

36. I wait patiently when it takes long to receive feedback.

47. I forget about my assignment when I have to wait long for feedback.

56. I complain when I have to wait long for feedback.

\subsection{5}

0.674

0.758

0.492

0.682

*FE: Students' Feelings When Receiving Feedback. FEWL: Students' Feelings When Waiting Long for Feedback.

As displayed in Table 3, the results reveal nine items (Item 6, 15, 27, 33, 38, 46, 49, 53, 55) that loaded significantly under F4 (FE). The mean scores of these items show that students feel mostly cared for $\left(\mathrm{M}_{38}=1.79\right)$ when they receive feedback. They also feel assessed $\left(\mathrm{M}_{53}=1.91\right)$, satisfied $\left(\mathrm{M}_{55}=2.13, \mathrm{M}_{33}=4.03\right)$ and improved $\left(\mathrm{M}_{49}=2.16\right)$. Students did not state negative feelings such as feeling humiliated or frustrated $\left(\mathrm{M}_{27}=\right.$ 4.22, $\left.\mathrm{M}_{6}=4.16\right)$. However, although not highly rated, some students did get demotivated or disappointed in some cases upon receiving their feedback $\left(\mathrm{M}_{15}=3.95, \mathrm{M}_{46}=3.75\right)$. Overall, students' feelings were mostly positive toward receiving feedback and the majority of them viewed feedback as a sign of their teacher's care. Excerpt 5 from one student summarizes these feelings:

\section{Excerpt 5:}

I feel great when I have positive comments. And when I have corrections, I try to find out how I can correct them. I do not want to have a low mark, so I have to be careful not to do the same mistakes again. At the end of the day, the teacher gives feedback for our benefit, and I have improved a lot by her help". (Mehmet)

The second subcategory in the scale consisted of six statements directed toward students' feelings in case of waiting too long to receive feedback (Items 7, 20, 34, 36, 47, 56) and they were factored under F5 (FEWL). Accordingly, having to wait long led students to feel demotivated $\left(\mathrm{M}_{7}=2.63\right)$ or to become impatient $\left(\mathrm{M}_{34}=\right.$ 2.85, $\mathrm{M}_{36}=4.22$ ). However, although not highly rated, becoming frustrated, forgetting the assignment or complaining were among the feelings students encountered $\left(\mathrm{M}_{20}=3.25, \mathrm{M}_{47}=3.05, \mathrm{M}_{56}=3.29\right)$. All in all, students expressed mostly negative feelings when they have to wait for too long for their feedback.

In order to identify any significant difference between FE and FEWL factors, the Wilcoxon Signed Ranks Test was conducted. The results of the analysis revealed a significant difference (Negative Mean Rank $=228.51$; Positive Mean Rank $=208.85 ; \mathrm{Z}=-3.237 ; \mathrm{p}=0.01<0.05)$, which indicates that students emotional dispositions toward timely feedback were different from those when waiting too long. The interview results supported the findings of the questionnaire. When interviewed, the majority of students $(n=17)$ stated that they might get confused or feel lost among the writing assignments and could forget the content of their writing in case of waiting too long for feedback. The following excerpt displays one reason for such a negative feeling:

Excerpt 6:

It affects me when I wait long because it affects my other assignment since I may make the same mistakes in the following essays again and this will slow down my progress. Maybe I will get low marks”. (Görkem)

The overall results for students' feelings indicate that although students' affective dispositions toward feedback are mostly positive, these emotional states transform into negative if they have to wait too long to receive their feedback.

\subsection{Students' Action Duration upon Feedback}

The last subcategory in the scale included items that aimed to find out when students take an action upon receiving feedback from their teachers. The four items in this subcategory loaded significantly and formed F6 (ACD) (Items 4, 11, 16, and 25). The factor loadings are presented in Table 4: 
Table 4. Item loadings for students' action initiation time upon receiving feedback

\begin{tabular}{ll}
\hline Items & Factor 6 (ACD) \\
\hline 4. I start revising right after receiving feedback. & 0.750 \\
11. I never revise after receiving feedback. & -0.689 \\
16. I start revising on the same week of receiving feedback. & 0.628 \\
25. I start revising on the same day of receiving feedback. & 0.713
\end{tabular}

*ACD: Students' Action Initiation Duration

The means scores for these items reveal that students mostly did not wait long to take action upon receiving their feedback. The action initiation was right either after receiving their feedback $\left(\mathrm{M}_{4}=1.81\right)$ or on the same day $\left(\mathrm{M}_{25}=1.99\right)$. Students strongly disagreed to Item 11 , which stated that they never took an action upon feedback $\left(\mathrm{M}_{11}=4.41\right)$.

A further analysis was conducted to search for any possible correlations between FE and ACD. The results of Pearson Chi-Square Test indicate that there is a statistically significant relationship between students' emotional states and the time they pass to take an action ( $\mathrm{Phi}=879.36, \mathrm{df}=312, \mathrm{p}=0.00<0.05$ ). Positive feelings correlated highly with immediate actions while negative feelings resulted in later action initiation. This finding indicates that when students feel positive (e.g. motivated, satisfied, etc.), they start working on feedback quicker whereas negative feelings (e.g. frustrated, humiliated, etc.) may cause them to postpone action upon feedback.

\section{Discussion}

The present study mainly aimed at identifying students' opinions on various aspects of feedback provided them in their writing classes. The statistical analysis of the data helped us determine students' opinions on the types of feedback, its impact on their language improvement, their affective dispositions when receiving feedback and their response initiation time upon feedback.

In respect to the types of feedback, the analysis revealed that the feedback administered to students was mostly directed toward grammar and organizational considerations. Feedback on content matters, vocabulary usage, punctuation, and capitalization had relatively less frequency. When asked for their preferences, students' choices did not differ significantly from what they already received, which indicates that the aspects they get feedback on were consistent with their perceived needs. Students preferred to receive feedback for both content and form along with organizational aspects of writing.

Another focus of the study was to find out which feedback type was regarded as beneficial by students for their language improvement. According to the results, students found feedback on all aspects of writing to be beneficial for their foreign language improvement. While feedback on content matters, grammar, and vocabulary received the highest ratings, other aspects such as organization or spelling were rated with relatively lower frequencies. Contrary to the assumption that focusing on grammatical accuracy is not favoured by students (e.g. Sommers, 1982; Zamel, 1985; Truscott, 1996; Reid, 1998; Ferris, 2003), the results of our study supports the view that students prefer guidance in terms of formal accuracy as well (e.g. Lee, 1997; Polio, Fleck, \& Leder, 1998; Ferris \& Helt, 2000; Ashwell, 2000).

Considering students' feelings when receiving their feedback (FE), the results show positive affective dispositions. They generally felt cared for, improved and satisfied. However, the analysis for a possible correlation between students' feelings and the time they initiated their physical response on feedback (FE vs. ACD) showed a significant correlation between students' emotional dispositions toward the feedback they received and the time they spent to take an action upon it. When they felt positive, the initiation of their action was immediate; whereas feeling negative led to putting off their action. As researchers state (e.g. Bangert-Drowns, C. Kulik, J. Kulik, \& Morgan, 1991; Shute, 2008; Gielen et al., 2010), certain conditions under which feedback is given can determine students' dispositions. While some conditions contribute to positive perceptions, some can lead to negative reactions. Therefore, the results imply that providing timely feedback is important so as not to hinder students' active involvement in foreign language learning process.

In conclusion, as Hamp-Lyons (2001) suggests, there is a need for a new generation of teachers who view learning from a situated perspective and thus, encompass various aspects of a given learning situation and base the decisions related to providing feedback on the specific context by identifying students' needs and preferences. By providing learners with a sense of agency and control over the learning process, we can create an opportunity 
to enhance the effectiveness of feedback in writing classes (Lo \& Hyland, 2007). However, when trying to shape the feedback process in writing classes by integrating students' preferences, teachers need to give cautious decisions. While disregarding students' opinions and applying a top-down approach could fail to engage students actively in their learning, relying solely on students' feedback preferences, especially at beginner levels, could also be misleading. Instead, we can foster a cooperative learning environment which takes students' needs and expectations into consideration and molds them in the pedagogical and academic experience teachers bring in. The results of this present study are expected to provide such a first step toward shaping the feedback process in our context while attempting to provide an example situation to the field of second language writing instruction.

\section{References}

Amrhein, H. R., \& Nassaji, H. (2010). Written corrective feedback: What do students and teachers prefer and why? Canadian Journal of Applied Linguistics (CJAL)/Revue canadienne de linguistiqueappliquée (RCLA), 13(2), 95-127.

Ashwell, T. (2000). Patterns of teacher response to student writing in a multiple-draft composition classroom: Is content feedback followed by form feedback the best method? Journal of Second Language Writing, 9(3), 227-257.

Bailey, R., \& Garner, M. (2010). Is the feedback in higher education assessment worth the paper it is written on? Teachers' reflections on their practices. Teaching in Higher Education, 15(2), 187-198.

Balzer, W. K., Doherty, M. E., \& O’Connor, R. (1989). Effects of cognitive feed-back on performance. Psychological Bulletin, 106(3), 410-433.

Black, P., \& Wiliam, D. (1998). Assessment and classroom learning. Assessment in Education: Principles, Policy and Practice, 5, 7-74.

Bangert-Drowns, R., Kulik, C. L. C., Kulik, J. A., \& Morgan, M. (1991). The instructional effect of feedback in test-like events. Review of Educational Research, 61, 213-238.

Bryman, A., \& Cramer, D. (2003). Quantitative Data Analysis with SPSS Release 8 for Windows: A Guide for Social Scientists. London: Routhledge.

Cattell, R. B. (1966). The meaning and strategic use of factor analysis. In R. B. Cattell (Ed.), Handbook of Multivariate Experimental Psychology (pp. 288-329). Chicago: Rand McNally.

Cronbach, L. J. (1951). Coefficient alpha and the internal structure of tests. Psychometrika, 16, 297-334.

Diab, R. L. (2005). Teachers' and students' beliefs about responding to ESL writing: A case study. TESL Canada Journal, 23, 28-43.

Ferris, D. R. (1995). Student reactions to teacher response in multiple-draft composition classrooms. TESOL Quarterly, 29, 33-53.

Ferris, D. R. (1997). The influence of teacher commentary on student revision. TESOL Quarterly, 31, 315-339.

Ferris, D. R. (1999). The case for grammar correction in L2 writing classes: A response to Truscott (1996). Journal of Second Language Writing, 8(1), 1-11.

Ferris, D. R. (2002). Treatment of error in second language student writing. Ann Arbor: The University of Michigan Press.

Ferris, D. R. (2003). Response to student writing: Implications for second language students. Mahwah, NJ: Lawrence Erlbaum Associates.

Ferris, D. R., \& Helt, M. (2000). Was Truscott right? New evidence on the effects of error correction in L2 writing classes. Paper presented at the American Association of Applied Linguistics Conference in Vancouver, B. C. March 11-14, 2000.

Frantzen, D. (1995). The effects of grammar supplementation on written accuracy in an intermediate Spanish content course. Modern Language Journal, 79, 244-329.

Gielen, S., Peeters, E., Dochy, F., Onghena, P., \& Struyyen, K. (2010). Improving the effectiveness of peer feedback for learning. Learning and Instruction, 20, 304-315.

Gorsuch, R. L. (1983). Factor Analysis. Hillside, NJ: Erlbaum.

Goldstein, L. M. (2005). Teacher written commentary in second language writing classrooms. Ann Arbor: The University of Michigan Press. 
Hamp-Lyons, L. (2001). Fourth generation writing assessment. In T. Silva, \& P. K. Matsuda (Eds.), On second language writing (pp. 117-128). Mahwah, NJ: Lawrence Erlbaum.

Hodkinson, P. M., \& Hodkinson, H. D. (1999). Teaching to Learn, learning to teach? School based non-teaching activity in an initial teacher education and training partnership scheme. Teaching \& Teacher Education, 15, 273-285.

Hyland, F. (1998). The impact of teacher written feedback on individual writers. Journal of Second Language Writing, 7, 255-286.

Hyland, K., \& Hyland, F. (2006a). Feedback on second language students' writing. Language Teaching, 39(2), 83-101.

Hyland, K., \& Hyland, F. (2006b). Interpersonal aspects of response: Constructing and interpreting teacher written feedback. In K. Hyland, \& F. Hyland (Eds.), Feedback in second language writing: Contexts and issues (pp. 206-224). Cambridge, UK: Cambridge University Press.

Hyland, F. (2010). Future directions in feedback on second language writing: Overview and research agenda. International Journal of English Studies, 10(2), 171-182. http://dx.doi.org/10.6018/ijes.10.2.119251

Inoue, A. B. (2005). Community-based assessment pedagogy. Assessing Writing, 9(3), 208-238.

Joughin, G. (2008). Assessment, learning and judgement in higher education. Springer: London.

Kalayci, S. (2010). SPSS Uygulamali çok değişkenli istatistik teknikleri. Ankara, Turkey: Asil Publishing.

Kluger, A. N., \& Denisi, A. (1998). Feedback interventions: Toward the understanding of a double-edged sword. Current Directions in Psychological Science, 7(3), 67-72.

Krashen, S. D. (1984). Writing: Research, Theory, and Application. Oxford: Pergamon.

Lee, I. (1997). Peer reviews in Hong Kong tertiary classroom. TESL Canada Journal, 15, 58-69.

Lee, I. (2005). Error correction in the L2 classroom: What do students think? TESL Canada Journal, 22, 1-16.

Lee, I. (2007). Feedback in Hong Kong secondary writing classrooms: Assessment for learning or assessment of learning? Assessing Writing, 12, 180-198.

Leki, I. (1991). The preferences of ESL students for error correction in college-level-writing classes. Foreign Language Annals, 24, 203-218.

Li, J., \& Barnard, R. (2011). Academic Tutors' Beliefs about and practices of giving feedback on students' written assignments: A New Zealand Case study. Assessing Writing, 16, 137-148.

Lo, J., \& Hyland, F. (2007). Enhancing students' engagement and motivation in writing: The case of primary students in Hong Kong. Journal of Second Language Writing, 16, 219-234.

Master, P. (1995). Consciousness raising and article pedagogy. In D. Belcher, \& G. Braine (Eds.), Academic writing in a second language: Essays in research and pedagogy (pp. 183-205). Norwood, NJ: Ablex.

Montgomery, J., \& Baker, W. (2007). Teacher-written feedback: Student perceptions, teacher self-assessment and actual teacher performance. Journal of Second Language Writing, 16, 82-99.

Narciss, S. (2008). Feedback strategies for interactive learning tasks. In J. M. Spector, M. D. Merrill, J. Van Merrieünboer, \& M. P. Driscoll (Eds.), Handbook of research on educational communications and technology (3rd ed., pp. 125-143). New York: Erlbaum.

Parr, M. J., \& Timperley, H. S. (2010). Feedback to writing, assessment for teaching and learning and student progress. Assessing Writing, 15, 68-85.

Plonsky, L., \& Mills, S. V. (2006). An exploratory study of differing perceptions of error correction between a teacher and students: Bridging the gap. Northern Arizona University Applied Language Learning, 16, 55-77.

Polio, C., Fleck, C., \& Leder, N. (1998). "If only I had more time”: ESL learners' changes in linguistic accuracy on essay revisions. Journal of Second Language Writing, 7, 43-68.

Radecki, P. M., \& Swales, J. M. (1988). ESL student reaction to written comments on their written work. System, 16, 355-365.

Raimes, A. (1991). Errors: Windows into the mind. College ESL, 1(2), 55-64.

Reid, J. (1998). "Eye" learners and "ear" learners: Identifying the language needs of international students and 
U.S. resident writers. In P. Byrd, \& J. M. Reid (Eds.), Grammar in the composition classroom: Essays on teaching ESL for college-bound students (pp. 3-17). Boston: Heinle \& Heinle.

Saito, H. (1994). Teachers' practices and students' preferences for feedback on second language writing: A case study of adult ESL learners. TESL Canada Journal, 11(2), 46-70.

Schulz, R. A. (1996). Focus on form in the foreign language classroom: Students' and teachers' views on error correction and the role of grammar. Foreign Language Annals, 29, 343-364.

Schulz, R. A. (2001). Cultural differences in student and teacher perceptions concerning the role of grammar instruction and corrective feedback: USA-Columbia. Modern Language Journal, 85, 244-258.

Semke, H. D. (1984). Effects of the red pen. Foreign Language Annals, 17(3), 195-202.

Shute, V. J. (2008). Focus on formative feedback. Review of Educational Research, 78, 153-189.

Sommers, N. (1982). Responding to student writing. College Composition and Communication, 33, 148-156.

Strijbos, J. W., Narciss, S., \& Dunnebier, K. (2010). Peer feedback content and sender's competence level in academic writing revision tasks: Are they critical for feedback perceptions and efficiency? Learning and Instruction, 20(4), 291-303.

Taylor, B. P. (1981). Content and written form: A two-way street. TESOL Quarterly, 15, 5-13.

Truscott, J. (1996). The case against grammar correction in L2 writing classes. Language Learning, 46(2), 327-369.

White, R., \& Arndt, V. (1991). Process Writing. Harlow: Longman.

Wiliam, D. (2001). An overview of the relationship between assessment and the curriculum. In D. Scoot (Ed.), Curriculum and assessment (pp. 165-181). Westport, CT: Ablex Publishing.

Zamel, V. (1985). Responding to student writing. TESOL Quarterly, 21, 697-715.

\section{Copyrights}

Copyright for this article is retained by the author(s), with first publication rights granted to the journal.

This is an open-access article distributed under the terms and conditions of the Creative Commons Attribution license (http://creativecommons.org/licenses/by/3.0/). 